\title{
Pengaruh Komunikasi Pemasaran Sales Promotion Terhadap Loyalitas Pengguna Aplikasi Transportasi Online (Survei pada

\author{
Pengguna Grab Bike)
}

\author{
Nelviluvita, Roswita Oktavianti \\ Nelviluvita.915160007@stu.untar.ac.id,Roswitao@fikom.untar.ac.id \\ Fakultas Ilmu Komunikasi Universitas Tarumanagara
}

\begin{abstract}
Marketing communication is a tool used by companies to convey information to the public. One of the marketing communication tools which selected in this research is sales promotion. Sales promotion is a tool used by companies to increase the level of product's sales by making repeated purchases or creating a loyalty. Loyalty is repeated usage of the same product. The purpose of this research is to determine whether there is an influence of sales promotion marketing communication towards the loyalty of online transportation applications users. One of the providers of online transportation applications in Indonesia is Grab Bike. The research approach is quantitative using survey methode. The author spread a questionnaire using purposive sampling techniques. After spreading the survey, the author gathers answers from respondents and processes the questionnaire results using SPSS application version 19. The results of this study concluded that sales promotion marketing communication affected $25.5 \%$ towards the loyalty of Grab Bike transportation applications users while $74.6 \%$ of the respondents is influenced by factors other than research. There is a positive relation between sales promotion marketing communication towards the loyalty of Grab Bike transportation application users. If the sales promotion marketing communication is further improved, the loyalty of Grab bike transportation application's users will also increase.
\end{abstract}

Keywords: online transportation applications, sales promotion marketing communication, user loyalty.

\begin{abstract}
Abstrak
Komunikasi pemasaran merupakan alat yang digunakan oleh perusahaan untuk menyampaikan informasi kepada masyarakat. Salah satu alat komunikasi pemasaran yang dipilih dalam penelitian ini adalah sales promotion. Sales promotion merupakan alat yang digunakan perusahaan untuk menaikkan tingkat penjualan suatu produk serta menciptakan pembelian yang berulang atau menciptakan loyalitas. Loyalitas merupakan penggunaan secara berulang terhadap suatu produk yang sama. Penelitian ini bertujuan untuk mengetahui apakah terdapat pengaruh komunikasi pemasaran sales promotion terhadap loyalitas pengguna aplikasi transportasi online. Salah satu penyedia aplikasi transportasi online di Indonesia adalah Grab bike. Pendekatan penelitian adalah kuantitatif dengan menggunakan metode survei. Penulis menyebarkan kuesioner tersebut menggunakan teknik purposive sampling. Setelah menyebarkan kuesioner, penulis mendapatkan jawaban dari responden dan mengolah hasil kuesioner menggunakan aplikasi SPSS versi 19. Dari hasil penelitian ini disimpulkan bahwa komunikasi pemasaran sales promotion memiliki pengaruh sebesar 25,5\% terhadap loyalitas pengguna aplikasi transportasi Grab bike, sedangkan 74,6\% dipengaruhi faktor lain di luar penelitian. Terdapat hubungan positif antara komunikasi pemasaran sales promotion terhadap loyalitas pengguna aplikasi transportasi Grab bike. Apabila
\end{abstract}


komunikasi pemasaran sales promotion lebih ditingkatkan maka tingkat loyalitas pengguna aplikasi transportasi Grab bike akan ikut meningkat.

Kata Kunci: komunikasi pemasaran, sales promotion, loyalitas pengguna, aplikasi transportasi online.

\section{Pendahuluan}

Kemajuan dibidang aplikasi transportasi online membawa kemudahan bagi masyarakat, khususnya di Indonesia sebagai sarana transportasi. Transportasi online adalah perusahaan yang menyediakan aplikasi berdasarkan teknologi dibidang transportasi darat dengan menggunakan sistem elektronik (https://finance.detik.com/berita-ekonomi-bisnis/d-4473985/ini-aturan-lengkap-ojekonline-yang-baru-terbit, diakses tanggal 11 September 2019, pukul 21.00).

Salah satu perusahaan penyedia aplikasi transportasi online yang sedang berkembang di Indonesia adalah Grab. Grab didirikan pada tahun 2012 dengan sebutan MyTeksi dan telah ada di delapan negara di seluruh Asia Tenggara. Grab menyediakan beberapa layanan jasa online (https://www.grab.com/id/brand-story/, diakses tanggal 18 September 2019, pukul 22.00). Salah satu jenis layanan jasa online yang penulis gunakan dalam penelitian ini adalah Grab bike.

Komunikasi pemasaran adalah salah satu usaha perusahaan yang dilakukan secara sadar atau tidak sadar dalam mengingatkan, menginformasikan, meyakinkan konsumen terhadap produk yang mereka pasarkan (Kotler dan Keller, 2008 :172). Salah satu model dari komunikasi pemasaran yang digunakan dalam penelitian ini adalah sales promotion.

Sales promotion merupakan alat yang digunakan oleh perusahaan untuk memasarkan produk, meningkatkan jumlah pemasaran secara tajam dalam waktu yang telah ditentukan (Priansa, 2017). Menurut penelitian Suherman Kusniadji tahun 2009, dengan judul penelitian "Strategi Komunikasi Pemasaran Dalam Kegiatan Pemasaran Produk Consumer Goods (Studi Kasus Pada PT Expand Berlian Mulia Di Semarang)", sales promotion memegang peran yang sangat penting dalam pemasaran produk karena promosi memiliki kemampuan untuk menggugah minat semua orang yang menjadi target sasaran tergerak untuk melakukan pembelian. Setelah dilakukanya sales promotion, perusahaan mengharapkan terjadinya timbal balik berupa kesetiaan konsumen atau terciptanya loyalitas.

Menurut Kotler dan Keller, loyalitas pelanggan merupakan banyaknya harapan konsumen melakukan pembelian produk perusahaan secara berulang (Hutapea, Ginting, Sutarman, 2017). Loyalitas merupakan hal yang diharapkan setiap perusahaan. Salah satunya perusahaan yang sedang berkembang di Indonesia, khususnya di bidang transportasi online.

Penelitian ini bertujuan untuk mengetahui apakah terdapat pengaruh antara komunikasi pemasaran sales promotion terhadap loyalitas pengguna aplikasi transportasi online. Pendekatan penelitian ini adalah kuantitatif dengan metode survei. Survei dalam penelitian ini dilakukan dengan menyebarkan kuesioner online dan kuesioner disebarkan menggunakan teknik purposive sampling dengan karakteristik yang telah ditetapkan oleh penulis. 


\section{Metode Penelitian}

\section{Gambar 1: Variabel X dan Variabel Y}

\begin{tabular}{|c|}
\hline Variabel X \\
Komunikasi Pemasaran \\
Terpadu \\
- Sales Promotion. \\
Promosi \\
Perdagangan \\
Point Of \\
Purchases Display \\
(POP) \\
Promosi bagi \\
Pelanggan Langsung \\
Price Deals \\
Kupon
\end{tabular}

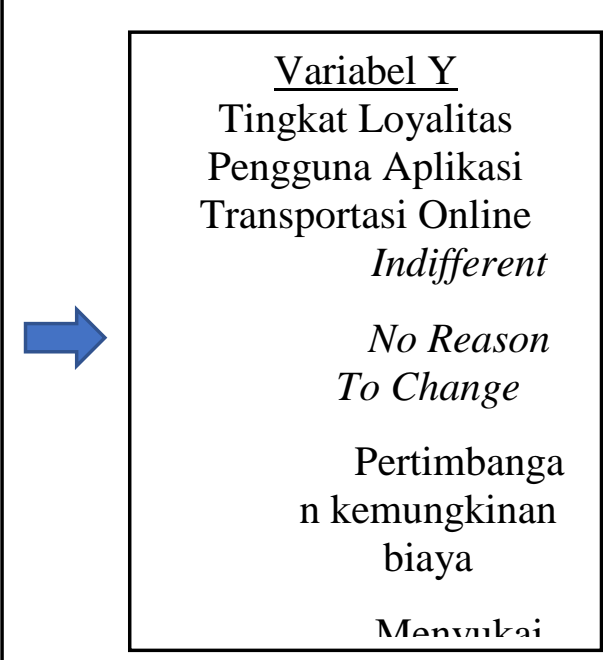

Sumber: diolah dari Priansa (2017) dan Sadat (2009)

Pendekatan dalam penelitian ini adalah kuantitatif dengan metode survei. Metode survei adalah metode yang dipakai untuk mendapatkan hasil dari lokasi yang telah ditentukan dan dipastikan secara kaidah yang telah ditetapkan, melainkan melakukan pengumpulan data menggunakan kuesioner, wawancara terstruktur, tes dan lainnya (Sugiyono, 2017).

Populasi dalam penelitian ini adalah pengguna yang memiliki aplikasi Grab bike, berdomisili di Jakarta. Peneliti mengambil 135 sampel pengguna aplikasi Grab bike yang pernah menggunakan komunikasi pemasaran sales promotion yang diberikan oleh Grab.

Hair et al mendefinisikan jumlah sampel yang cocok bagi penelitian adalah 100 atau lebih dari 100, sehingga total sampel harus di kali lima (dalam Pratita, Pratikto \& Sutrisno, 2018).

$$
\begin{gathered}
\mathrm{N} \text { minimum }=5 \mathrm{x} \text { Jumlah indikator } \\
\mathrm{N} \text { minimum }=135
\end{gathered}
$$

Teknik pengambilan sampel menggunakan teknik non probability dengan teknik purposive sampling. Teknik purposive sampling merupakan teknik yang digunakan untuk menentukan sampel dengan apa yang telah ditentukan (Sugiyono, 2018).

Berikut indikator yang terdapat didalam penelitian ini:

A. Indikator Variabel X (Komunikasi Sales Promotion):

1. Promosi perdagangan

Point of purchases display (POP): yaitu promosi dengan menggunakan tempat pajangan yang dilakukan dalam jangka waktu tertentu.

2. Promosi bagi pelanggan langsung

a). Price Deals: potongan yang diberikan secara otomatis oleh perusahaan. 
b). Kupon: yaitu potongan yang diberikan oleh perusahaan dalam bentuk kupon dengan jangka waktu tertentu.

c). Hadiah Loyalitas Pelanggan: yaitu hadiah yang diberikan oleh pelanggan atas penggunaan layanan jasa aplikasi perusahaan, hadiah ini berbentuk poin yang dapat ditukarkan.

d).Promosi Gabungan: yaitu kerja sama antara perusahaan dengan perusahaan lainnya untuk melakukan kegiatan promosi dan mendapatkan keuntungan (Priansa, 2017: 126-127).

A. Indikator variabel Y (Loyalitas pengguna):

1. Indifferent: pengguna senang berganti ke aplikasi transportasi lainnya dikarenakan adanya perbedaan harga.

2. No Reason To Change: pengguna merasa senang dengan perusahaan dan melakukan penggunaan kembali karena terbiasa.

3. Pertimbangan kemungkinan biaya: pengguna memiliki pilihan untuk pindah tetapi tidak dilakukan karena adanya peretimbangan harga, waktu, resiko dan lainnya.

4. Menyukai Merek: pengguna telah menyukai merek dan menggunakan aplikasi perusahaan sebagai pendamping kesehariannya.

5. Komitmen: pengguna tidak mau menggunakan aplikasi yang lainnya meskipun promo yang diberikan perusahaan tidak sebanyak dulu (Sadat, 2009:171).

Teknik pengumpulan data dalam penelitian ini adalah menggunakan kuesioner online jenis tertutup. Kuesioner tertutup adalah kuesioner yang tidak memberikan responden dalam mengeluarkan pendapat dan telah ditentukan dalam butir pilihan ganda (Siregar, 2013).

\section{Hasil Temuan dan Diskusi}

Setelah menyebarkan kuesioner, data yang didapatkan diolah dengan menggunakan program hitung SPSS versi 19. Berikut hasil uji validitas yang telah penulis dapatkan dari hasil olahan SPSS versi 19:

Tabel 1. Hasil Uji Validitas Variabel X (Komunikasi Pemasaran Sales promotion)

\begin{tabular}{cccl}
\hline X & $\begin{array}{c}\text { cted Item- Total } \\
\text { Correlation }\end{array}$ & lai Patokan & Keterangan \\
\hline SP1 & 0,302 & 0,2 & Valid \\
\hline SP2 & 0,389 & 0,2 & Valid \\
\hline SP3 & 0,329 & 0,2 & Valid \\
\hline SP4 & 0,576 & 0,2 & Valid \\
\hline SP5 & 0,592 & 0,2 & Valid \\
\hline SP6 & 0,609 & 0,2 & Valid \\
\hline SP7 & 0,621 & 0,2 & Valid \\
\hline SP8 & 0,603 & 0,2 & Valid \\
\hline SP9 & 0,464 & 0,2 & Valid \\
\hline SP10 & 0,439 & 0,2 & Valid \\
\hline
\end{tabular}




\begin{tabular}{cccc}
\hline SP11 & 0,594 & 0,2 & Valid \\
\hline SP12 & 0,661 & 0,2 & Valid \\
\hline \multicolumn{4}{c}{ Sumber: Hasil Olahan Data SPSS ver.19 }
\end{tabular}

Berdasarkan Tabel 1, diketahui hasil uji validitas variabel $\mathrm{X}$, dari 12 item pernyataan variabel komunikasi pemasaran sales promotion dinyatakan valid karena nilai dari Corrected Item- Total Correlation lebih besar dari 0,2. Valid dalam penelitian ini diartikan bahwa setiap item pernyataan sesuai dengan tujuan penelitian.

\begin{tabular}{cccc}
\multicolumn{5}{c}{ Tabel 2. Hasil Uji Validitas Variabel Y (Loyalitas Pengguna) } \\
\hline \multicolumn{5}{c}{$\begin{array}{c}\text { ted Item- Total } \\
\text { Correlation }\end{array}$} \\
\hline L1 & 0,302 & 0,2 & Valid \\
\hline L2 & 0,368 & 0,2 & Valid \\
\hline L3 & 0,599 & 0,2 & Valid \\
\hline L4 & 0,59 & 0,2 & Valid \\
\hline L5 & 0,761 & 0,2 & Valid \\
\hline L6 & 0,539 & 0,2 & Valid \\
\hline L7 & 0,758 & 0,2 & Valid \\
\hline L8 & 0,722 & 0,2 & Valid \\
\hline L9 & 0,637 & 0,2 & Valid \\
\hline L10 & 0,730 & 0,2 & Valid \\
\hline L11 & 0,704 & 0,2 & Valid \\
\hline L12 & 0,752 & 0,2 & Valid \\
\hline L13 & 0,733 & 0,2 & Valid \\
\hline L14 & 0,776 & 0,2 & Valid \\
\hline L15 & 0,583 & 0,2 & Valid \\
\hline & & & \\
\hline
\end{tabular}

Sumber: Hasil Olahan Data SPSS ver.19

Berdasarkan Tabel 2, diketahui hasil uji validitas variabel Y dari 15 item pernyataan variabel loyalitas pengguna dinyatakan valid karena nilai dari Corrected Item- Total Correlation lebih besar dari 0,2.

Tabel 3. Hasil Uji Reliabilitas Variabel X (Komunikasi Pemasaran Sales Promotion) Reliability Statistics

\begin{tabular}{|c|c|}
\hline $\begin{array}{c}\text { Cronbach's } \\
\text { Alpha }\end{array}$ & N of Items \\
\hline, 838 & 12 \\
\hline
\end{tabular}


Berdasarkan Tabel 3, hasil uji reliabilitas variabel X (Komunikasi Pemasaran Sales Promotion) mempunyai nilai Cronbach's Alpha sebesar 0,838 yang artinya variabel komunikasi pemasaran sales promotion reliabel karena nilai Alpa Cronbach $>0,6$.

Tabel 4. Hasil Uji Reliabilitas Variabel Y (Loyalitas Pengguna)

Reliability Statistics

\begin{tabular}{|c|c|}
\hline $\begin{array}{c}\text { Cronbach's } \\
\text { Alpha }\end{array}$ & N of Items \\
\hline, 921 & 15 \\
\hline
\end{tabular}

Sumber: Hasil Olahan Data SPSS ver.19

Berdasarkan Tabel 4, hasil uji reliabilitas variabel Y (Loyalitas Pengguna) mempunyai nilai Cronbach's Alpha sebesar 0,921 yang artinya variabel komunikasi pemasaran sales promotion reliabel karena nilai Alpha Cronbach $>0,6$.

Tabel 5. Hasil Uji Normalitas

One-Sample Kolmogorov-Smirnov Test

\begin{tabular}{|ll|l|}
\hline & & $\begin{array}{l}\text { Unstandardize } \\
\text { d Residual }\end{array}$ \\
\hline N & & 135 \\
Normal Parameters ${ }^{\text {a,b }}$ & Mean & 0E-7 \\
& Std. Deviation & $\mathbf{6 , 2 5 9 6 7 8 1 2}$ \\
& Absolute & $\mathbf{1 0 1}$ \\
Most Extreme Differences & Positive & $\mathbf{, 0 5 0}$ \\
& Negative & $-\mathbf{1 0 1}$ \\
Kolmogorov-Smirnov Z & & $\mathbf{1 , 1 7 1}$ \\
Asymp. Sig. (2-tailed) & &, 129 \\
\hline
\end{tabular}

a. Test distribution is Normal.

b. Calculated from data.

Sumber: Hasil Olahan Data SPSS ver.19

Berdasarkan uji One Sample Kolmogorov-Smirnov pada Tabel 5, hasil uji normalitas menunjukkan nilai signifikan sebesar 0,129 sehingga data dalam penelitian ini berdistribusi normal karena hasil signifikan lebih besar dari 0,05. Berdistribusi normal dalam penelitian ini dapat diartikan data yang diperoleh dalam penelitian ini bisa digeneralisasikan ke pada populasi.

Tabel 6. Hasil Uji Koefisien Korelasi

Model Summary ${ }^{b}$

\begin{tabular}{|l|r|r|r|c|}
\hline Model & \multicolumn{1}{|c|}{$\mathrm{R}$} & R Square & $\begin{array}{c}\text { Adjusted R } \\
\text { Square }\end{array}$ & $\begin{array}{c}\text { Std. Error of the } \\
\text { Estimate }\end{array}$ \\
\hline 1 &, $504^{\mathrm{a}}$ &, 254 &, 248 & 6,283 \\
\hline
\end{tabular}

a. Predictors: (Constant), Sales Promotion

b. Dependent Variable: Loyalitas 
Berdasarkan hasil uji koefisien korelasi pada Tabel 6, hasil uji koefisien korelasi $(\mathrm{R})$ dari variabel $\mathrm{X}$ (Komunikasi pemasaran sales promotion) terhadap variabel Y (Loyalitas Pengguna) dalam penelitian ini sebesar 0,504. Hasil uji koefisien korelasi berada direntan 0,40-0,599, sehingga dapat disimpulkan bahwa kekuatan hubungan antara komunikasi pemasaran sales promotion dan loyalitas pengguna adalah sedang. Hubungan korelasi sedang dalam hasil uji koefisien korelasi ini menunjukkan adanya hubungan positif antara komunikasi pemasaran sales promotion terhadap loyalitas pengguna, yang artinya apabila komunikasi pemasaran sales promotion lebih ditingkatkan maka tingkat loyalitas pengguna akan meningkat dan apabila komunikasi sales promotion turun maka tingkat loyalitas pengguna akan ikut menurun.

Tabel 7. Hasil Uji Koefisien Determinasi

Model Summary ${ }^{b}$

\begin{tabular}{|l|r|r|r|c|}
\hline Model & \multicolumn{1}{|c|}{$\mathrm{R}$} & R Square & \multicolumn{1}{c|}{$\begin{array}{c}\text { Adjusted R } \\
\text { Square }\end{array}$} & $\begin{array}{c}\text { Std. Error of the } \\
\text { Estimate }\end{array}$ \\
\hline 1 &, $504^{\mathrm{a}}$ &, 254 &, 248 & 6,283 \\
\hline
\end{tabular}

a. Predictors: (Constant), Sales Promotion

Dependent Variable: Loyalitas

Sumber: Hasil Olahan Data SPSS ver.19

Dari hasil uji koefisien determinasi pada Tabel 7, diperoleh nilai dari kolom $\mathrm{R}$ Square sebesar 0,254 atau 25,4\%. Hal ini menunjukkan bahwa loyalitas pengguna dapat dijelaskan sebesar 25,4\% oleh variabel independen yaitu komunikasi pemasaran sales promotion. Sedangkan $74,6 \%$ dipengaruhi oleh faktor-faktor lain di luar variabel independen penelitian ini.

Tabel 8. Hasil Uji Analisis Regresi Linier Sederhana

\section{Coefficients $^{\mathrm{a}}$}

\begin{tabular}{|c|c|c|c|c|c|}
\hline \multirow{2}{*}{ Model } & \multicolumn{2}{|c|}{$\begin{array}{c}\text { Unstandardized } \\
\text { Coefficients }\end{array}$} & $\begin{array}{c}\text { Standardized } \\
\text { Coefficients }\end{array}$ & \multirow{2}{*}{ Sig. } & \\
\cline { 2 - 4 } & $\mathrm{B}$ & Std. Error & Beta & & \\
\hline \multirow{2}{*}{1 (Constant) } & 11,140 & 5,058 & & 2,203 &, 029 \\
Sales Promotion &, 822 &, 122 &, 504 & 6,724 &, 000 \\
\hline
\end{tabular}

a. Dependent Variable: Loyalitas

Sumber: Hasil Olahan Data SPSS ver.19

Dari hasil uji persamaan regresi linier sederhana pada Tabel 8, maka dapat disimpulkan, nilai sebesar 11,140 menyatakan konstanta dari fungsi regresi yang menunjukkan bahwa tidak ada kenaikan variabel X (Komunikasi Pemasaran Sales Promotion), maka variabel Y (Loyalitas Pengguna) akan mencapai 11,140. Apabila mengalami penambahan atau perubahan variabel X (Komunikasi Pemasaran Sales Promotion), maka variabel Y (Loyalitas Pengguna) akan mengalami perubahan sebanyak 0,822 .

$$
\begin{aligned}
& \quad \begin{array}{l}
\text { Rumus untuk mengetahui } t_{\text {tabel }} \text { sebagai berikut: } \\
\mathrm{t}(\alpha / 2 ; \mathrm{n}-\mathrm{k}-1)
\end{array} \\
& =\mathrm{t}(0,05 / 2 ; 135-1-1)
\end{aligned}
$$


Berdasarkan Tabel 8, dapat diketahui hasil analisis regresi diperoleh koefisien untuk variabel komunikasi pemasaran sales promotion sebesar 0,822 dengan konstanta sebesar 11,140.

Hasil uji nilai t pengaruh komunikasi pemasaran sales promotion terhadap loyalitas pengguna menunjukkan nilai $t_{\text {hitung }} 6,724$, dan $\mathrm{p}$ value (Sig) sebesar 0,000. Maka dapat disimpulkan bahwa $t_{\text {hitung }} \geq t_{\text {tabel }}$ yaitu 6,724 $\geq 1,996$ dan nilai $\operatorname{sig}<\alpha$ yaitu $0,000<0,05$, yang artinya ada pengaruh antara komunikasi pemasaran sales promotion terhadap loyalitas pengguna. Oleh karena itu, dapat disimpulkan juga bahwa hipotesis alternatif (Ha) diterima, yaitu terdapat pengaruh komunikasi pemasaran dalam bentuk sales promotion terhadap loyalitas pengguna aplikasi transportasi online, sedangkan hipotesis nol (Ho) ditolak, yaitu tidak terdapat pengaruh antara komunikasi pemasaran dalam bentuk sales promotion terhadap pengguna aplikasi transportasi online.

\section{Simpulan}

Dari hasil penelitian terdapat pengaruh antara komunikasi pemasaran sales promotion terhadap loyalitas pengguna aplikasi transportasi Grab bike sebesar 25,4\% dan sisanya $74,6 \%$ dipengaruhi oleh faktor-faktor lain diluar variabel independen yang dilakukan penulis. Hubungan yang didapatkan dari hasil pengolahan data ini adalah hubungan positif yang bersifat sedang antara variabel komunikasi pemasaran sales promotion terhadap loyalitas pengguna transportasi Grab bike, sehingga apabila komunikasi pemasaran sales promotion lebih ditingkatkan maka tingkat loyalitas pengguna transportasi Grab bike juga akan meningkat.

Saran dari peneliti adalah bagi peneliti selanjutnya, penulis berharap dapat melakukan penelitian menggunakan jenis komunikasi pemasaran lainnya untuk menguji pengaruh loyalitas pengguna aplikasi transportasi online.

\section{Ucapan Terimakasih}

Ucapan terimakasih penulis kepada 135 responden penelitian dan semua pihak yang terlibat dalam pembuatan penelitian ini.

\section{Daftar Pustaka}

Afriyadi, Achmad Dwi. (2019, Maret 19). Aturan Lengkap Gojek Yang Baru Terbit. September 11, 2019. Detik Finance. https://finance.detik.com/berita-ekonomibisnis/d-4473985/ini-aturan-lengkap-ojek-online-yang-baru-terbit

Astri, Bernadeta Wahyu., Pratita., Pratikto Heri., Sutrisno. (2018). Analisis FaktorFaktor yang Mempengaruhi Keputusan Pembelian Pelanggan di Kober Bar Malang. Jurnal Pendidikan, 3 (4), 497-503. Oktober 7, 2019. Terarsip di: http://journal.um.ac.id/index.php/jptpp/

Grab Indonesia. (n.d). Tentang Grab. September 18, 2019. (https://www.grab.com/id/brand-story/)

Hutapea, Katrin. E., Ginting, Paham., Sutarman. (2017). Pengaruh Kepuasan Terhadap Loyalitas Dengan Switching Cost Sebagai Variabel Intervening Pada Pelanggan Provider Prepaid Telkomsel Di Kota Medan. Jurnal Konsep Bisnis dan Manajemen, 3 (1), 87. September 11, 2019. Terarsip di: http://dx.doi.org/10.31289/jkbm.v3i2.344 
Kotler, Philip dan Keller, Kevin. L. (2008). Manajemen Pemasaran. (Ed.13). (Bob Sabran, Adi Maulana \& Wibi Hardani, Penerjemah \& Editor). Jilid 1. Jakarta: Erlangga

Kotler, Philip dan Keller, Kevin. L. (2008). Manajemen Pemasaran. (Ed.13). Jilid 2. Jakarta: Erlangga

Kusniadji, Suherman. (2009). Strategi Komunikasi Pemasaran Dalam Kegiatan Pemasaran Produk Consumer Goods (Studi Kasus Pada PT Expand Berlian Mulia Di Semarang). Jurnal Komunikasi, 8 (1), 83-98. September 12, 2019. Terarsip di: http://dx.doi.org/10.24912/jk.v8i1.49

Priansa, Donni Juni. (2017). Komunikasi Pemasaran Terpadu Pada Era Media Sosial. Bandung: CV. Pustaka Setia

Sadat, Andi.M. (2009). Brand Belief: Membangun Merek Berbasis Keyakinan. Jakarta: Salemba Empat

Siregar, Syofian. (2013). Metode Penelitian Kuantitatif: Dilengkapi dengan Perbandingan Perhitungan Manual \& SPSS. Jakarta: Prenadamedia Group

Sugiyono. (2018). Metode Penelitian Kuantitatif. (Ed.1). Bandung: Alfabeta, CV.

Sugiyono. (2017). Metode Penelitian Kuantitatif, Kualitatif, dan R\&D. (Ed.26). Bandung: Alfabeta, CV. 